\title{
Antiviral Activities and Putative Identification of Compounds in Microbial Extracts from the Hawaiian Coastal Waters
}

\author{
Jing Tong ${ }^{1,2}$, Hank Trapido-Rosenthal ${ }^{3}$, Jun Wang ${ }^{4}$, Youwei Wang ${ }^{2}$, Qing X. Li ${ }^{4, *}$ and \\ Yuanan Lu ${ }^{1, *}$
}

1 Department of Public Health Sciences, University of Hawaii at Manoa, East-West Road, Honolulu, HI 96822, USA; E-Mail: tongjing1975@yahoo.com.cn

2 Key Laboratory of Combinatorial Biosynthesis and Drug Discovery (Wuhan University), Ministry of Education, and Institute of Traditional Chinese Medicine \& Natural Products, School of Pharmaceutical Sciences, Wuhan University, Wuhan 430071, China;

E-Mail: wyw@wbgcas.cn

3 Center for Marine Microbial Ecology and Diversity, University of Hawaii at Manoa, Honolulu, HI 96822, USA; E-Mail: rosenthl@hawaii.edu

Department of Molecular Biosciences and Bioengineering, University of Hawaii at Manoa, East-West Road, Honolulu, HI 96822, USA; E-Mail: wangjun2@hawaii.edu

* Authors to whom correspondence should be addressed; E-Mails: yuanan@ hawaii.edu (Y.L.); qingl@hawaii.edu (Q.X.L.); Tel.: +1-808-956-2702 (Y.L.); +1-808-956-2011 (Q.X.L.); Fax: +1-808-956-5818(Y.L.); +1-808-956-3542 (Q.X.L.).

Received: 25 December 2011; in revised form: 3 February 2012 / Accepted: 6 February 2012 / Published: 24 February 2012

\begin{abstract}
Marine environments are a rich source of significant bioactive compounds. The Hawaiian archipelago, located in the middle of the Pacific Ocean, hosts diverse microorganisms, including many endemic species. Thirty-eight microbial extracts from Hawaiian coastal waters were evaluated for their antiviral activity against four mammalian viruses including herpes simplex virus type one (HSV-1), vesicular stomatitis virus (VSV), vaccinia virus and poliovirus type one (poliovirus-1) using in vitro cell culture assay. Nine of the 38 microbial crude extracts showed antiviral potencies and three of these nine microbial extracts exhibited significant activity against the enveloped viruses. A secosteroid, $5 \alpha(\mathrm{H}), 17 \alpha(\mathrm{H}),(20 R)$-beta-acetoxyergost-8(14)-ene was putatively identified and confirmed to be the active compound in these marine microbial extracts. These results warrant future in-depth tests on the isolation of these active elements in order to explore and validate their antiviral potential as important therapeutic remedies.
\end{abstract}


Keywords: marine extract; antiviral drug; antiviral activity; enveloped virus; secosteroids

\section{Introduction}

Viruses are known to cause a variety of infectious diseases which threaten public health. The search for new therapeutic agents to control virus infection is one of the highest priorities in virological research. Oceans represent a virtually untapped resource for the discovery of novel bioactive compounds [1]. The Census of Marine Life Project recently increased the estimate of marine species from more than 230,000 to at least one million marine organisms, and tens or even hundreds of millions of different microbes, such as protists, bacteria and archaea [2]. Secondary metabolites with various biological activities can be induced as a result of the complicated marine environment, some of which represent a valuable resource waiting to be discovered for the treatment of infectious diseases [3]. Hundreds of new compounds are reportedly identified from marine species each year [3], and several marine bioactive metabolites have been successfully developed by the pharmaceutical industry [4]. The Hawaiian archipelago, located in the middle of the Pacific Ocean, is the most isolated group of islands in the world [5]. Because of its unique geographical location, the Hawaiian tropical marine ecosystem promotes the generation of a higher percentage of endemic species relative to other tropical regions [6]. In this study, we have particularly tested some marine microbial extracts prepared from Hawaiian coastal waters to evaluate their antiviral activities.

Marine organisms have proven to produce many important therapeutic agents and are a continued focus for drug discovery [7]. The diversity of organisms in the marine environment has inspired researchers for many years to identify active compounds for clinical treatment of infectious diseases, including antifungal, antibacterial, antiprotozoal and antiviral activities. Each year hundreds of new bioactive compounds from marine environments are discovered and some have been approved as new therapeutic drugs by the Food and Drug Administration (FDA) and the European Agency for the Evaluation of Medicinal Products (EMEA). These include cytarabine (Cytosar- $\mathrm{U}^{\circledR}$, Depocyt ${ }^{\circledR}$ ), vidarabine $\left(\right.$ Vira- $\left.{ }^{\circledR}\right)$, ziconotide $\left(\right.$ Prialt $^{\circledR}$ ) and trabectedin (Yondelis ${ }^{\circledR}$ ) [8].

To explore marine compounds for antiviral potential, more than 2,000 crude extracts from a variety of marine organisms, including sponges, bacteria and algae, have been prepared in our laboratories. A cell line bank has also been established, comprising more than 150 cell lines derived from various organs and tissues of different animal species. The objectives of this study were to (1) establish an in vitro model system to screen marine microbial extracts for their antiviral potential; (2) evaluate 38 marine crude extracts for their antiviral potency and (3) isolate and identify bioactive compounds in marine microbial crude extracts. Four representative viruses isolated from mammal species collected and prepared in the Environmental Health Laboratory at the University of Hawaii at Manoa were tested in this study (Table 1). 
Table 1. Four viruses used for the antiviral activity tests with the Vero host cells from the African Green Monkey kidney epithelial cells.

\begin{tabular}{llll}
\hline Viruses & Viral Family & Enveloped & Structure \\
\hline $\begin{array}{l}\text { Herpes simplex virus type } \\
\text { one (HSV-1) }\end{array}$ & Herpesviridae & Yes & Linear double-stranded DNA genome \\
$\begin{array}{l}\text { Vesicular stomatitis virus } \\
\text { (VSV) }\end{array}$ & Rhabdoviridae & Yes & Single-stranded negative-sense RNA genome \\
$\begin{array}{l}\text { Vaccinia virus } \\
\begin{array}{l}\text { Polio virus type one } \\
\text { (poliovirus-1) }\end{array}\end{array}$ & $\begin{array}{l}\text { Poxvirus } \\
\text { Picornaviridae }\end{array}$ & Yes & $\begin{array}{l}\text { Linear double-stranded DNA genome } \\
\text { Single-stranded positive-sense RNA genome }\end{array}$ \\
\hline
\end{tabular}

\section{Results and Discussion}

\subsection{Extract Cytotoxicity}

Figure 1. Cytotoxic sensitivities of Vero cells to selected marine microbial extracts. (* Samples with significant differences among different concentrations in ANOVA tests. Vero cell at their exponential growth phase were seeded in 96-well plates and then exposed to different concentrations of selected marine extracts (4 wells per concentration). Following a 2-day incubation time at $37^{\circ} \mathrm{C}$, cell viability was determined using MTT assay by measuring absorbance reading at $492 \mathrm{~nm}$. Results shown represent mean values of cell viability from two independent experiments and error bars denote the standard deviation.)

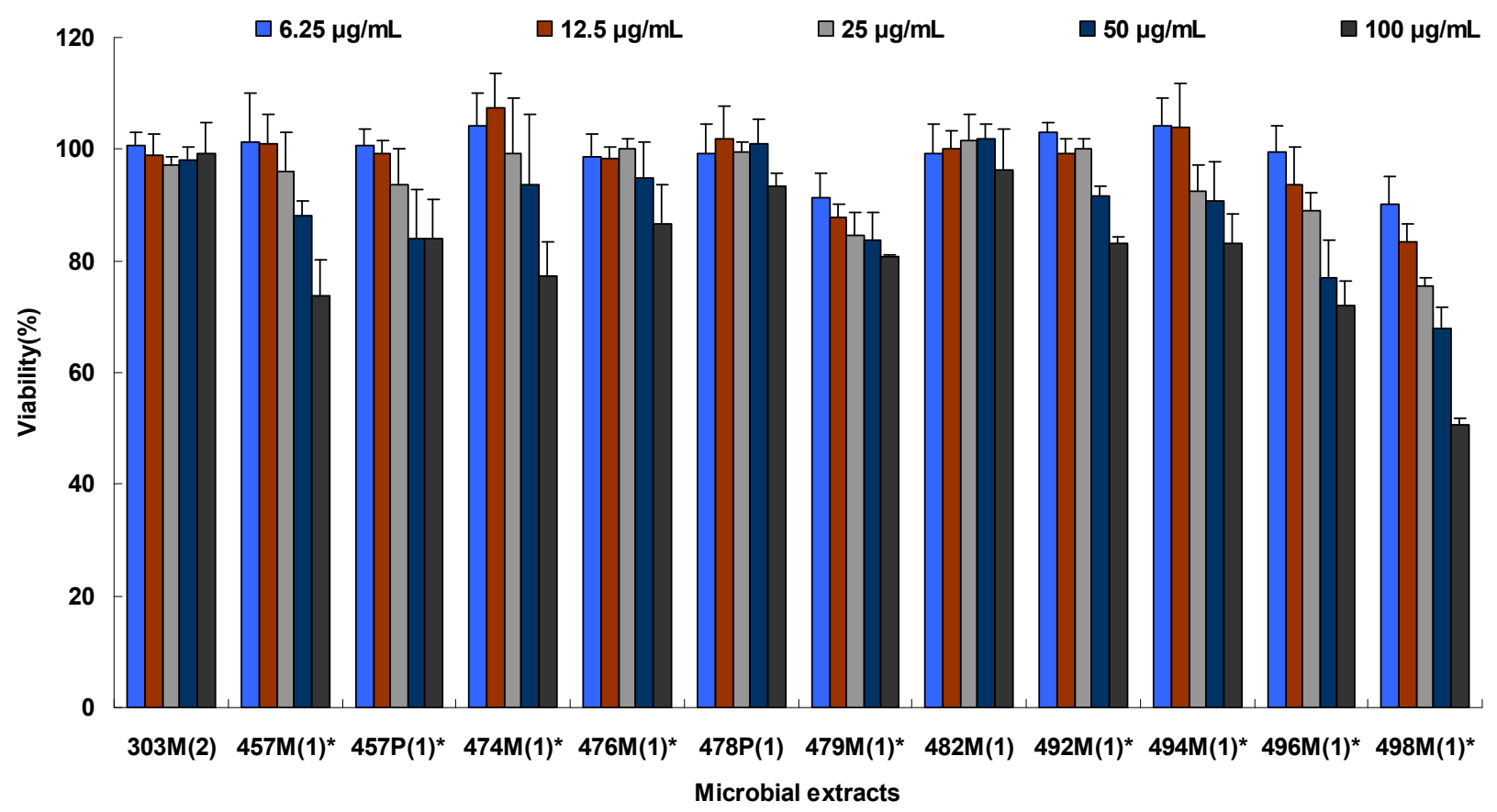

To assess properly the antiviral effect of the crude marine extracts, a set of experimental tests were performed to determine a safe and effective dose of these extracts to be used for antiviral experimental tests in vitro. $10 \%$ inhibition concentration $\left(\mathrm{IC}_{10}\right)$ values were calculated by SPSS 16.0 [9]. Experimental results revealed that crude extracts $219 \mathrm{P}(3), 258 \mathrm{M}(1), 258 \mathrm{P}(1), 331 \mathrm{P}(3), 435 \mathrm{P}(1)$, $464 \mathrm{P}(1), 478 \mathrm{M}(1), 496 \mathrm{P}(1), 497 \mathrm{P}(1)$ were toxic to Vero cells with $\mathrm{IC}_{10} \leq 5 \mu \mathrm{g} / \mathrm{mL}$, and one extract 
492P(1) was insoluble. These ten extracts were therefore not included in the antiviral assays. Extracts 62M(1), 62P(1), 226P(3), 298M(1), 298P(1), 397P(1), 456P(1), 457P(1), 457M(1), 460M(1), 474M(1), 476M(1), 479M(1), 485P(1), 485M(1), 492M(1), 494M(1), 495P(1), 496M(1) and 498M(1) showed variable levels of cytotoxicity with $\mathrm{IC}_{10}<100 \mu \mathrm{g} / \mathrm{mL}$ (Figure 1 and Table 2). Based on the calculated $\mathrm{IC}_{10}$, subtoxic concentrations of the 28 viable extracts were used in the latter experimental tests. For extracts demonstrating no toxicity to Vero cells at all tested concentrations, the highest concentration of $100 \mu \mathrm{g} / \mathrm{mL}$ was selected for the following antiviral experimental tests.

Table 2. Marine extracts and their cytotoxicity ${ }^{\mathrm{a}}$.

\begin{tabular}{|c|c|c|}
\hline Extracts $^{b}$ & Sources & $\mathrm{IC}_{10}(\mu \mathrm{g} / \mathrm{mL})$ \\
\hline $62 \mathrm{M}(1)$ & Oscillatoria sp.(Waikiki Aquarium) & $64.3 \pm 5.7$ \\
\hline $62 \mathrm{P}(1)$ & Oscillatoria sp.(Waikiki Aquarium) & $49.2 \pm 0.3$ \\
\hline 219P(3) & Pseudoalteromonas sp. from Mycale armata,Kaneohe Bay & $\leq 5.0$ \\
\hline 226P(3) & Pseudoalteromonas sp. from Mycale armata,Kaneohe Bay & $13.5 \pm 1.1$ \\
\hline $258 \mathrm{P}(1)$ & Oscillatoria sp. from Fresh water & $\leq 5.0$ \\
\hline 258P(1) & Oscillatoria sp. from Fresh water & $\leq 5.0$ \\
\hline $298 \mathrm{M}(1)$ & bacterium from Kaneohe Bay, yet to be taxonomically classified & $42.5 \pm 1.5$ \\
\hline 298P(1) & bacterium from Kaneohe Bay; yet to be taxonomically classified & $17.33 \pm 0.17$ \\
\hline $303 \mathrm{M}(2)$ & bacterium from Kaneohe Bay; yet to be taxonomically classified & $\geq 100$ \\
\hline $331 \mathrm{P}(3)$ & Achromobacter fischeri from Mycale armata, Kaneohe Bay & $\leq 5.0$ \\
\hline $397 \mathrm{M}(1)$ & bacterium from Kaneohe Bay; yet to be taxonomically classified & $\geq 100$ \\
\hline $397 \mathrm{P}(1)$ & bacterium from Kaneohe Bay; yet to be taxonomically classified & $6.5 \pm 0.4$ \\
\hline $435 \mathrm{P}(1)$ & $\begin{array}{l}\text { bacterium from Hawaii Ocean Time Series (HOTS) site; yet to be } \\
\text { taxonomically classified }\end{array}$ & $\leq 5.0$ \\
\hline $456 \mathrm{P}(1)$ & Marine bacterium from HOTS site; yet to be taxonomically classified & $9.1 \pm 0.2$ \\
\hline $457 \mathrm{M}(1)$ & Diatom, Amphora sp., from Great Salt Lake & $44.6 \pm 1.9$ \\
\hline $457 \mathrm{P}(1)$ & Diatom, Amphora sp., from Great Salt Lake & $51.7 \pm 2.3$ \\
\hline $460 \mathrm{M}(1)$ & bacterium from HOTS site; yet to be taxonomically classified & $22.5 \pm 3.2$ \\
\hline $464 \mathrm{P}(1)$ & bacterium from HOTS site; yet to be taxonomically classified & $\leq 5.0$ \\
\hline $474 \mathrm{M}(1)$ & bacterium; yet to be taxonomically classified & $63.1 \pm 4.2$ \\
\hline $475 \mathrm{M}(1)$ & bacterium; yet to be taxonomically classified & $\geq 100$ \\
\hline $476 \mathrm{M}(1)$ & bacterium; yet to be taxonomically classified & $48.9 \pm 3.0$ \\
\hline $477 \mathrm{P}(1)$ & bacterium; yet to be taxonomically classified & $\geq 100$ \\
\hline $478 \mathrm{M}(1)$ & bacterium; yet to be taxonomically classified & $\leq 5.0$ \\
\hline 478P(1) & bacterium; yet to be taxonomically classified & $\geq 100$ \\
\hline $479 \mathrm{M}(1)$ & bacterium; yet to be taxonomically classified & $7.4 \pm 0.5$ \\
\hline $482 \mathrm{M}(1)$ & bacterium; yet to be taxonomically classified & $\geq 100$ \\
\hline 483P(1) & bacterium; yet to be taxonomically classified & $\geq 100$ \\
\hline $485 \mathrm{M}(1)$ & bacterium; yet to be taxonomically classified & $68.9 \pm 5.8$ \\
\hline $485 \mathrm{P}(1)$ & bacterium; yet to be taxonomically classified & $54.8 \pm 4.7$ \\
\hline $492 \mathrm{M}(1)$ & bacterium; yet to be taxonomically classified & $61.0 \pm 3.2$ \\
\hline $492 \mathrm{P}(1)$ & bacterium; yet to be taxonomically classified & indissoluble \\
\hline $494 \mathrm{M}(1)$ & bacterium; yet to be taxonomically classified & $44.0 \pm 2.8$ \\
\hline $495 \mathrm{M}(1)$ & bacterium; yet to be taxonomically classified & $\geq 100$ \\
\hline $495 \mathrm{P}(1)$ & bacterium; yet to be taxonomically classified & $24.7 \pm 1.8$ \\
\hline
\end{tabular}


Table 2. Cont.

\begin{tabular}{llc}
\hline Extracts $^{\text {b }}$ & Sources & IC $_{\mathbf{1 0}}(\boldsymbol{\mu g} / \mathbf{m L})$ \\
\hline $496 \mathrm{M}(1)$ & bacterium; yet to be taxonomically classified & $16.2 \pm 1.3$ \\
$496 \mathrm{P}(1)$ & bacterium; yet to be taxonomically classified & $\leq 5.0$ \\
497P(1) & bacterium; yet to be taxonomically classified & $\leq 5.0$ \\
$498 \mathrm{M}(1)$ & bacterium; yet to be taxonomically classified & $6.6 \pm 0.6$ \\
\hline
\end{tabular}

${ }^{a}$ Cytotoxicity is expressed as extracts concentration causing $10 \%$ inhibition of cell proliferation $\left(\mathrm{IC}_{10}\right)$;

${ }^{\mathrm{b}}$ Each extract of marine microorganism was named, based on the following regulation. For example, extract $62 \mathrm{M}(1)$, where 62 denotes microorganism sequence number, cultured in the Center for Marine Microbial Ecology and Diversity and (1) denotes the first inoculation of this particular culture and subsequent inoculation of the same culture are labeled as (2), (3), etc. Cultures that had both the media/supernatant and pellet extracted are differentiated from one another by the addition of an $\mathrm{M}$ or $\mathrm{P}$ to the extracts sequence number to denote a media and pellet extraction. To harvest and extract marine bacteria, cultures were centrifuged at $5000 \mathrm{~g}$ for $20 \mathrm{~min}$. The supernatant was then extracted with ethyl acetate and the sediment extracted with methylene chloride: 2-propanol $(\mathrm{V} / \mathrm{V}, 2: 1)$. The extracts samples were then dissolved in DMSO with a concentration of $100 \mathrm{mg} / \mathrm{mL}$ and then used for screening.

\subsection{Viral Inhibition by Cell Pretreatment}

Selected extracts were first tested for their anti-viral effect during the adsorption phase by blocking cellular receptor. Following $1 \mathrm{~h}$ pre-incubation with these extracts, cells were then infected with test viruses. Our data demonstrated that none of the marine extracts were able to prevent test viruses from entering Vero cells under the test conditions described. This indicated the marine extract treatments had no effect on viral infection and replication during the pretreatment phase.

\subsection{Viral Inhibition by Virus Pretreatment}

The marine extracts were then tested for their ability to combat viral infection by blocking viral entry into the cells or through viral inactivation. A total of 28 marine extracts were tested. None of the extracts exhibited any antiviral impact against poliovirus-1. However, most of the extracts exhibited antiviral effects against HSV-1, vaccinia and VSV at different levels based on viral plaque formation (Figure 2). As shown in Table 3, a total of 18 extracts showed antiviral effects against HSV-1 in Vero cells. In particular, 457M(1), 457P(1), 478P(1), 482M(1), 492M(1) and 494M(1) possessed strong antiviral activity, and a single treatment with one of these extracts resulted in complete deprivation of HSV-1 infectivity, leading to neither viral plaque formation nor viral-induced cytopathic effect (CPE) of the affected cells. Seven extracts including 226P(3), 460M(1), 475M(1), 476M(1), 485M(1), 485P(1), and 496M(1) exhibited moderate inhibitory effects on HSV-1 while the five other extracts, 303M(2), 474M(1), 477P(1), 479M(1) and 498M(1) showed slight inhibitory anti-HSV-1 effects. 
Table 3. Marine microbial extracts and their antiviral effects in viral adsorption inhibition assay.

\begin{tabular}{|c|c|c|c|c|c|}
\hline Extracts & Concentrations $(\mu \mathrm{g} / \mathrm{mL})$ & HSV-1 & VSV & Vaccinia & Poliovirus-1 \\
\hline $62 \mathrm{M}(1)$ & 50 & - & - & - & - \\
\hline 62P(1) & 50 & - & +++ & - & - \\
\hline $226 \mathrm{P}(3)$ & 12.5 & ++ & - & - & - \\
\hline $298 \mathrm{M}(1)$ & 50 & - & +++ & - & - \\
\hline $298 \mathrm{P}(1)$ & 12.5 & - & ++ & - & - \\
\hline $303 \mathrm{M}(2)$ & 100 & + & +++ & + & - \\
\hline $397 \mathrm{M}(1)$ & 100 & - & - & - & - \\
\hline $397 \mathrm{P}(1)$ & 6.25 & - & - & - & - \\
\hline $456 \mathrm{P}(1)$ & 12.5 & - & - & - & - \\
\hline $457 \mathrm{M}(1)$ & 25.0 & +++ & +++ & +++ & - \\
\hline $457 \mathrm{P}(1)$ & 25.0 & +++ & +++ & +++ & - \\
\hline $460 \mathrm{M}(1)$ & 25.0 & ++ & ++ & - & - \\
\hline $474 \mathrm{M}(1)$ & 50.0 & + & +++ & ++ & - \\
\hline $475 \mathrm{M}(1)$ & 100 & ++ & ++ & + & - \\
\hline $476 \mathrm{M}(1)$ & 50.0 & ++ & +++ & ++ & - \\
\hline $477 \mathrm{P}(1)$ & 100 & + & + & ++ & - \\
\hline $478 \mathrm{P}(1)$ & 100 & +++ & + & +++ & - \\
\hline $479 \mathrm{M}(1)$ & 6.25 & + & +++ & +++ & - \\
\hline $482 \mathrm{M}(1)$ & 100 & +++ & +++ & +++ & - \\
\hline $483 \mathrm{P}(1)$ & 100 & - & - & - & - \\
\hline $485 \mathrm{M}(1)$ & 50.0 & ++ & ++ & ++ & - \\
\hline $485 \mathrm{P}(1)$ & 50.0 & ++ & - & ++ & - \\
\hline $492 \mathrm{M}(1)$ & 50.0 & +++ & ++ & ++ & - \\
\hline $494 \mathrm{M}(1)$ & 50.0 & +++ & ++ & ++ & - \\
\hline $495 \mathrm{M}(1)$ & 100 & - & - & - & - \\
\hline $495 \mathrm{P}(1)$ & 25.0 & - & - & - & - \\
\hline 496M(1) & 12.5 & ++ & +++ & ++ & - \\
\hline $498 \mathrm{M}(1)$ & 6.25 & + & +++ & ++ & - \\
\hline
\end{tabular}

-: no meaningful inhibition at subtoxic concentration; +: Slight inhibition $(\geq 20 \%$ and $<50 \%)$; ++: Moderate inhibition $(\geq 50 \%$ and $<80 \%$ ); +++ : High inhibition $(\geq 80 \%)$. 50-100 PFU/mL of virus diluted solution in serum-free medium and equal volumes of the extract dilutions were placed in a tube and mixtures incubated at room temperature for $1 \mathrm{~h}$. Serum-free medium without extract was used as a blank control. The samples were then placed on monolayers of Vero cells to absorb for $1 \mathrm{~h}$ at $37{ }^{\circ} \mathrm{C}$. The inhibition efficiency was assessed by counting plaques. Then the ratio of inhibition efficiency was calculated compared to the blank control.

As shown in Table 3 and Figure 2, the tested extracts also showed varied levels of antiviral impact against VSV. Eleven extracts including 62P(1), 298M(1), 303M(2), 457M(1), 457P(1), 474M(1), 476M(1) 479M(1), 482M(1), 496M(1) and 498M(1) showed strong antiviral activity, with 303M(2), 457P(1), 457M(1), 474M(1), 479M(1), 496M(1) and 498M(1) specifically resulting in complete viral inhibition evidenced by neither viral plaque formation nor virus-induced CPE appearance in Vero cells. In comparison, six extracts 298P(1), 460M(1), 475M(1), 485M(1), 492M(1) and 494M(1) exhibited a moderate antiviral effect and two extracts 477P(1) and 478P(1) showed slight viral inhibition while the remaining nine extracts showed no meaningful antiviral effect. 
Figure 2. Marine microbial extracts mediated anti-viral attachment and entry into Vero cells. (HSV-1 (Left), VSV (middle), and Vaccinia virus (right) were pre-incubated with selected marine extracts at subtoxic concentration, incubated in room temperature for $2 \mathrm{~h}$, and then used to infect Vero cells prepared in 24-well plates. Following $1 \mathrm{~h}$ viral adsorption, removed the viruses, then overlay medium was added and plates were transferred to $37{ }^{\circ} \mathrm{C}$ incubator for 36-48 h to allow viral plaque development. Plates were fixed and stained with crystal violet staining solution and photomicrographs were taken. Viral induced plaques were visually counted and marine extracts mediated inhibitory effect was determined by comparing the plaques produced in the control cultures.)
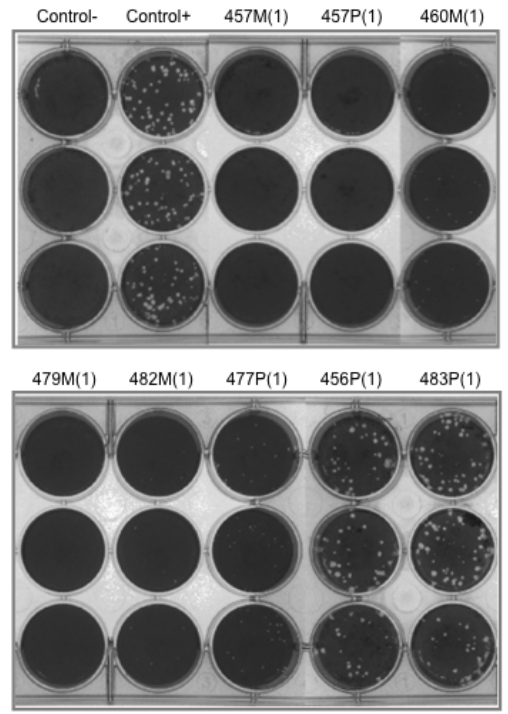
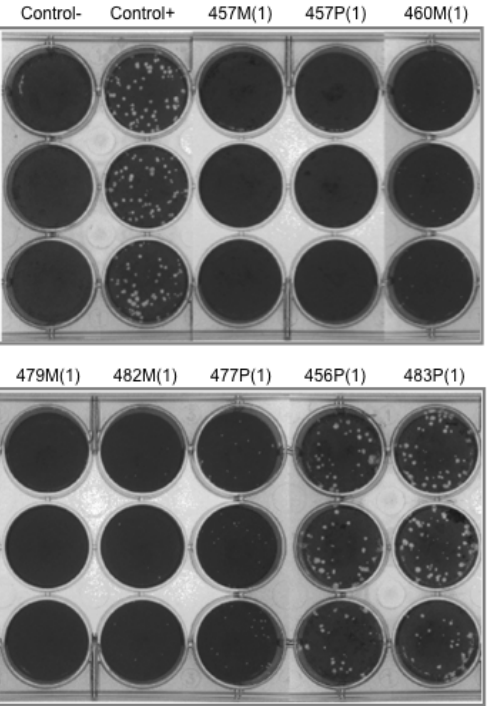
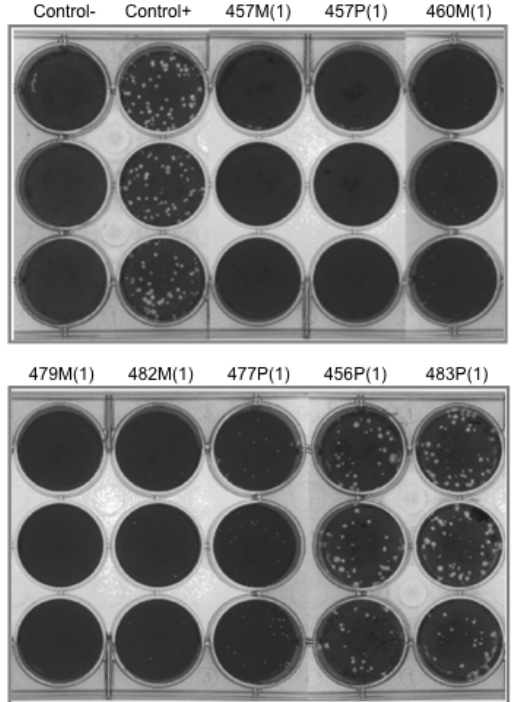

Similarly, these extracts also showed different antiviral effects on vaccinia virus as summarized in Table 3 and Figure 2. Among 28 marine extracts tested, extracts 457M(1), 457P(1), 478P(1), 479M(1) and $482 \mathrm{M}(1)$ showed strong antiviral activity, especially extracts $457 \mathrm{P}(1)$ and $457 \mathrm{M}(1)$ which completely blocked vaccinia infection in Vero cells. Nine other extracts 474M(1), 476M(1), 477P(1), 485M(1), 485P(1), 492M(1), 494M(1), 496M(1) and 498M(1) exhibited a moderate antiviral effect. Two extracts $303 \mathrm{M}(2)$ and $475 \mathrm{M}(1)$ showed slight inhibition, while the remaining twelve extracts showed no meaningful antiviral effect.

\subsection{Viral Replication Inhibition Assay}

In addition to antiviral attachment/entry studies, selected marine extracts were tested for their potential to disrupt the viral replication process. Results obtained from this study showed only a few marine extracts were able to interfere with viral replication in different efficiency. As shown in Figure 3, extract 298M(1) showed antiviral activity against poliovirus-1 and VSV. This inhibitory effect was evidenced by delaying the appearance of viral induced-CPE for $36 \mathrm{~h}$ and $48 \mathrm{~h}$, respectively as compared to the infected control cells. However, this antiviral effect, was not observed at $60 \mathrm{~h}$ after infected. Similarly, extracts 303M(1), 457P(1), 457M(1), 474M(1), 476M(1), 479M(1), 482M(1) and $496 \mathrm{M}(1)$ all showed some signs of against VSV replication at an early post-infection time point $(24 \mathrm{~h})$, however such antiviral effects vanished at $48 \mathrm{~h}$ post-infection. None of the other marine extracts tested 
showed apparent inhibitory property against the 4 selected viruses based on the measurement of viral replication and production by CPE (Figure 3).

Figure 3. Inhibitory effect of marine microbial extracts on viral replication. (Vero cells were seeded into T-12.5 $\mathrm{cm}^{2}$ flasks and then infected with VSV (A) or poliovirus-1 (B) at an MOI of 0.001 . Following $1 \mathrm{~h}$ viral adsorption, culture fluid was completely removed and infected cells were washed three times and then incubated with the medium containing selected marine extracts at subtoxic concentrations. Photomicrographs were taken to show the progression of viral-induced CPE at selected post-infection times. In addition, delayed progression of CPE in the presence of marine extracts $298 \mathrm{M}(1)$ was documented compared to control cells under the same experimental condition except with no marine extract.)

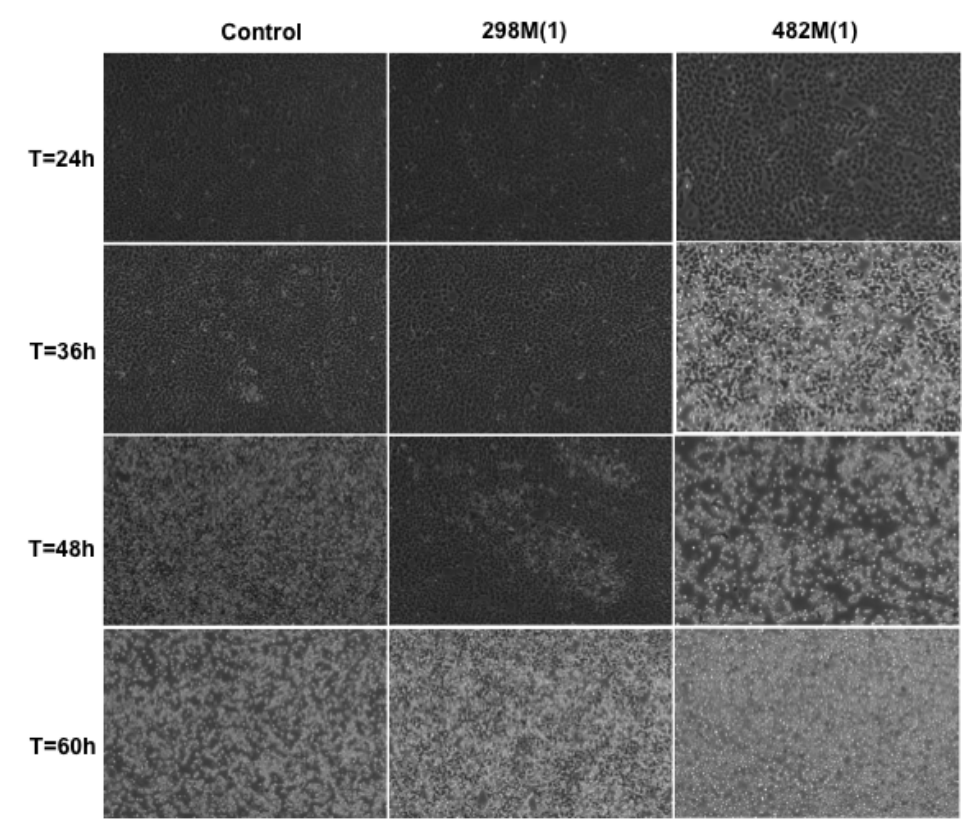

(A)

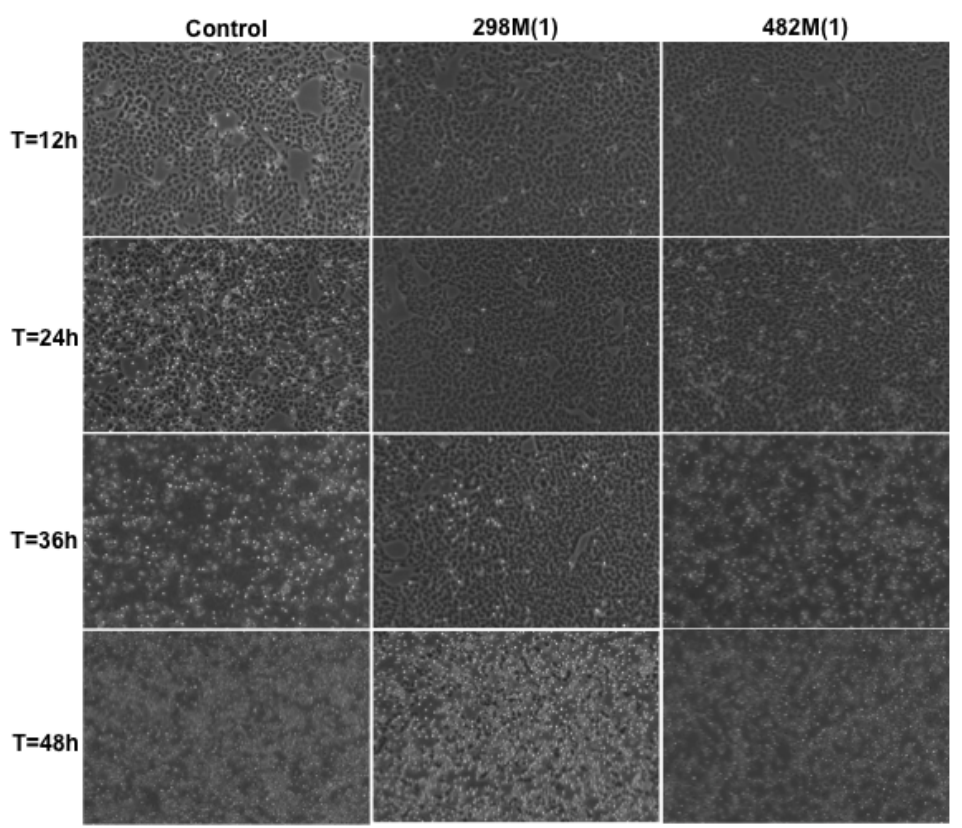

(B) 


\subsection{Isolation and Identification of Antiviral Components in Crude Extracts}

Figure 4 presents typical GC/ITMS chromatograms of marine microbial crude extracts including blank control, standard, 298P(1), 457P(1), 474M(1), 476M(1), and 495M(1). Results show that the peak of arrow point is the most commonly monitored compound in all marine microbial crude extracts with antiviral activity such as $298 \mathrm{P}(1), 457 \mathrm{P}(1), 474 \mathrm{M}(1)$, and $476 \mathrm{M}(1)$. In addition, analytical results also show that the commonly monitored peak in GC/ITMS chromatograms was included in all 4 extracts tested with antiviral activity. However, the commonly monitored peak in GC/ITMS chromatograms was not detected in 3 marine microbial crude extracts 456P(1), 495M(1), and 496P(1), which have no antiviral activity.

Figure 4. GC/ITMS chromatograms of marine microbial crude extracts including blank control, standard, 298M(1), 457P(1), 474M(1), 476M(1) and 495M(1). (A) Mass peak of target compound in marine microbial crude extracts; (B) Mass peak of standard in database of GC-ITMS workstation. Arrow point denotes target compound.
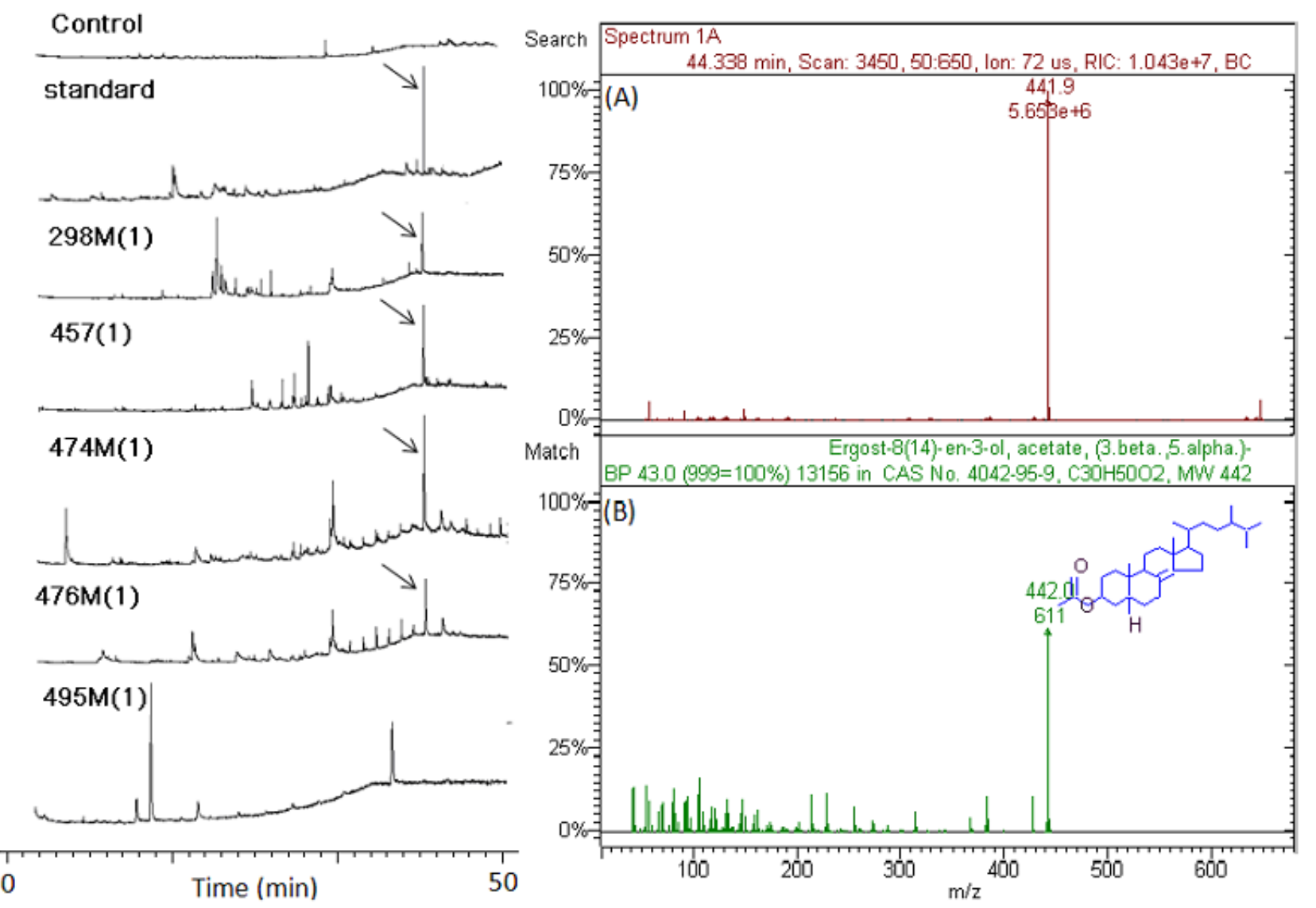

Matching the mass spectra and GC retention times with its standard identified a significant compound, secosteroid. Secosteroids are highly oxidized metabolites with bond cleavage in the rings of the steroid tetracyclic nucleus. All secosteroids are grouped in accordance with their ring joined to side chain as 5,6-, 9,11-, 9,10- 8,9-, 8,14- and 13,17-secosteroids and the structures and synthetic works, where available, are reported. A review describes the isolation from marine organisms of all secosteroids reported in the literature from 1972 to 2004 and gives details on the biological activities 
of the isolated secosteroids (e.g., antiproliferative, antifouling, anti-inflammatory, antimicrobial, ichthyotoxic and antiviral) [10].

\subsection{Discussion}

Testing marine natural products for their therapeutic potential has been a continued focus for new drug development and such effort has led to the discovery of many important therapeutic agents. The global marine preclinical pipeline reported a total of 592 marine compounds with antitumor activity for the period of 1998-2006, and 666 additional chemicals with a variety of pharmacological activities including antibacterial, anticoagulant, anti-inflammatory, antifungal, anthelmintic, antiplatelet, antiprotozoal and antiviral activities. In addition, these chemicals also showed some effect on the cardiovascular, endocrine, immune, and nervous systems [11,12]. To extend the current effort for the discovery of new antiviral drug from marine environment, 38 newly-prepared extracts from marine microorganisms isolated from Hawaiian waters were tested for their antiviral effect against four mammalian viruses. Our screening study demonstrated that some of these extracts are highly active against the test viruses ( $>80 \%$ viral inactivation), particularly to enveloped viruses.

Prior to the screening of marine extracts for their antiviral activity, a set of experimental tests was carried out to determine the maximum safe dose of these extracts to be used in test cell cultures. Since these extracts were crude preparations and not purified compounds, they were tested at $100 \mu \mathrm{g} / \mathrm{mL}$, the maximum test concentration according to Verkman's drug discovery theory [13]. Any extract producing $10 \%$ or more reduction in cell viability was considered to be toxic and $\mathrm{IC}_{10}$ values were calculated as the subtoxic concentration in the latter experimental tests in this study.

Antiviral activity of these marine extracts was evaluated by using three different methods. First, the extracts were tested for their ability to prevent viral infection by blocking cellular receptors of permissive cells. Data obtained from viral infectivity tests showed that the pretreatment of Vero cells with these extracts resulted in no apparent reduction of viral plaque formation, suggesting these extracts have no preventive effect on initial viral infection. Similarly, screening of the marine extracts for possible disruption of viral application revealed that none of the extracts was affective. Exception for a few extracts which exhibited limited antiviral activity against VSV and poliovirus-1 during early phase of viral replication, treatment with the extracts resulted in no apparent decrease in viral production in test cells as compared to untreated control cells evaluated by the appearance and development of viral-induced CPE and the production of infectious virus particles.

Lastly, the marine extracts were tested for their ability to combat viral infection by blocking viral attachment/entry into the cells and our experimental results demonstrated that several marine extracts are highly inhibitory to all enveloped viruses tested, including VSV, HSV-1 and vaccinia virus. However, none of these extracts showed any antiviral activity against naked poliovirus-1. These findings suggest that the observed viral inactivation appears to be envelope-based but non-viral specific since VSV, HSV-1 and vaccinia are classified into three different viral families. Although little is currently known regarding the mechanism relating to the observed viral inactivation, the formation of a stable virion-complex with any compound that has special structures in these extracts may be the explanation. It is known that the occupancy or denaturation of viral surface proteins can lead to the loss of viral ability to interact with host cells. 
Because of the limited number of marine extracts tested in this study, it is impossible to claim a clear correlation between antiviral activity and the extract's organism of origin. However, the present study showed that some extracts from marine bacterial species have antiviral potential. This finding is consistent with previous reports from several other groups indicating the virus inactivating capacity from marine bacterial species [14-17]. Current screening of natural products derived from marine microbial species has identified metabolites with significant antiviral activity, although only a few were derived from marine bacterial species [18]. This may be largely due to the limited amount of studies focused on finding bioactive compounds from a few marine bacteria, such as exopolysaccharides and macrolactin A. Undoubtedly, continuous screening of more extracts from marine bacteria will enhance present pharmaceutical development by the discovery of more potential antiviral molecules from marine bacteria. In particular, since the low abundance of the natural producers and/or the low concentrations of the compounds of interest have had a limiting effect, hampering the development of new marine drugs, and the highly complex structures of many marine metabolites also make synthetic approaches for their development economically daunting, the biomedical potential of marine bacterial agents that can be amenable to biotechnological production might overcome these problems based on the supply and sustainability of microorganisms from the sea.

This study also indicated that some extracts from marine diatoms including 457P(1) and 457M(1) (Diatom, Amphora sp.) are highly active against all three enveloped viruses: HSV-1, VSV and vaccinia. This result is in agreement with the findings from our previous study [19] and the report by Lee and co-workers who demonstrated the bioactive compound naviculan isolated from diatom species (Navicula directa) to have antiviral activities against herpes simplex viruses 1 and 2, and influenza A virus [20]. These findings together suggest the importance and essentiality of exploring additional marine diatom extracts for antiviral compounds. The diatoms represent a large and extraordinary ecologically flexible group of unicellular eukaryotic photosynthetic microalgae. The species diversity of diatoms is large, with estimated species range from $1 \times 10^{4}$ to $2 \times 10^{5}$ [21], which constitute one of the major components of the phytoplankton in both freshwater and marine environments [22]. However, little is currently known about bioactive substances in diatoms, as compared to other abundant aquatic microorganisms like cyanobacteria and dinoflagellates [23]. Therefore, testing and evaluation of extracts and compounds from marine diatom species will become a major research focus on discovering marine antiviral drugs and other therapeutic remedies for humans in future.

It is notable that several extracts showed antiviral activity against VSV, HSV-1 and vaccinia, but the antiviral capacity among these three enveloped viruses is quite different. In particular, extracts 298M(1), 303M(2), 496M(1) and 62P(1) exhibited much more potent antiviral effects or viral inactivation activity against VSV as compared to the other two viruses. This selective anti-VSV tendency documented in the previous report [18] may be due to the nature of the envelope proteins of rhabdoviruses. VSV is a virus member belonging to Rhabdoviridae family and comprises a helical ribonucleocapsid surrounded by a lipid bilayer covered by trimers of a single type of an integral glycoprotein, named G protein. Cell recognition and fusion are mediated by VSV surface glycoprotein $\mathrm{G}$ and then viral entry thorough endocytosis followed by low-pH-induced membrane fusion [24]. On the other hand, extracts $457 \mathrm{P}(1), 457 \mathrm{M}(1)$ and $482 \mathrm{M}(1)$ all showed the highly potential antiviral effect across all tested enveloped viruses, this may suggest that the glycoproteins of these enveloped viruses are the viral component responsible for the reaction with any fractions of these extracts. Future study is necessary in order to confirm and fully understand this observation. 
To explore and identify any component of marine extracts with antiviral potential responsible for the observed antiviral effect, representative extracts were further extracted and then analyzed by GC-ITMS. A compound, $5 \alpha(H), 17 \alpha(H),(20 R)-\beta$-Acetoxyergost-8(14)-ene was putatively identified by matching its mass spectra and GC retention times with its standard in almost all microbial extracts tested with antiviral activity in the present study. $5 \alpha(H), 17 \alpha(H),(20 R)$ - $\beta$-Acetoxyergost-8(14)-ene belongs to secosteroids, highly oxidized metabolites with bond cleavage in the rings of the steroid tetracyclic nucleus. The first marine secosteroid to be described was discovered in the gorgonian Pseudopterogorgia americana in 1972 [25]. The majority of secosteroids has been isolated from sponges, gorgonians, soft corals and from the ascidian Aplidium conicum [10]. The characterization of secosteroids was made possible by the continuing improvement of the separation techniques and the introduction of new identification methods. Currently we cannot explain the biological function and the mechanism of the biosynthesis of these novel modified steroids. However, secosteroids have been reported to have diverse biological activities, e.g., antiproliferative, antifouling, anti-inflammatory, antimicrobial, ichthyotoxic and antiviral [10].

In summary, screening of 38 extracts from marine bacteria, diatoms and other microorganisms allowed the identification of several extracts with potent antiviral activity, particularly on viral inactivation for enveloped viruses. Among the tested samples, extracts 457M(1), 457P(1) and 482M(1) revealed to have antiviral potential with a broad-spectrum of viruses. However, the observed inhibition does not seem sufficient to suggest the application of these microbial extracts as treatment of an established viral infection. Since these extracts have the potential to be used as prophylactic agents to prevent viral infection, as well as preventing viral spread as evidenced by the high level of viral inactivation without cytotoxicity, it would be important and of interest for future studies to focus on the isolation of the active fractions and purified compounds from these extracts. Identification of active individual chemical components of the extracts and study of their chemical properties against specific viral genomic or proteomic components will lead to the understanding of direct anti-viral mechanisms and facilitate their development as new antiviral drugs.

\section{Experimental Section}

\subsection{Cell Culture and Media}

Green Africa monkey kidney (Vero) cells (ATCC, Manassas, VA, USA, Cat, No. CCL-81TM) were grown with Dulbecco's Modified Eagle Media (DMEM) (Sigma-Aldrich, St. Louis, MO, USA) supplemented with 10\% heat-inactivated bovine calf serum (BCS) (Hyclone, Logan, UT, USA) and 1\% GPS solution containing $4 \mathrm{mM}$ L-glutamine (Sigma-Aldrich), $100 \mathrm{U} / \mathrm{mL}$ penicillin and $100 \mu \mathrm{g} / \mathrm{mL}$ streptomycin sulfate at $37{ }^{\circ} \mathrm{C}$ with humidified $5.0 \% \mathrm{CO}_{2}$.

\subsection{Virus Stock Preparation}

The viral isolates (Table 1), their replication and purification and quantitative infection assays have been established and routinely used in the laboratory, University of Hawaii at Manoa [26]. These model viruses were propagated and quantified. Briefly, Vero cells were grown and seeded into TC-75 $\mathrm{cm}^{2}$ flasks, as described above, so that an approximately $90 \%$ cell monolayer formed in $24 \mathrm{~h}$. All medium 
was removed from the flask and the cells were infected with $250 \mu \mathrm{L}$ previously prepared virus stock mixed together with $2 \mathrm{~mL}$ of serum-free medium. The flasks were incubated at $37^{\circ} \mathrm{C}$ for $1 \mathrm{~h}$ and then unadsorbed virus was removed by rinsing cell the monolayer twice with serum-free medium, and then $10 \mathrm{~mL} /$ flask virus replication medium containing 5\% BCS was added. The flasks were then incubated at $37{ }^{\circ} \mathrm{C}$ for viral infection and production. Flasks showing approximately $90 \% \mathrm{CPE}$ evidenced by visual appearance of rounding of cells, loss of contact inhibition and cell death were harvested and stored at $-80{ }^{\circ} \mathrm{C}$ for $24 \mathrm{~h}$. Following two cycles of freeze-thawing, the medium was collected from the flasks and centrifuged at $1000 \mathrm{rpm}$ for $5 \mathrm{~min}$ to remove cellular debris. Supernatant was then collected and aliquots of $0.5 \mathrm{~mL} /$ tube were stored long-term at $-80{ }^{\circ} \mathrm{C}$ or short-term at $-20{ }^{\circ} \mathrm{C}$.

\subsection{Marine Microbial Isolates}

Thirty-eight marine microbial isolates were obtained from Thomas Hemscheidt's laboratory at the University of Hawaii at Manoa. These microbial isolates were collected from sites around the Hawaiian coastal waters. Briefly, pure cultures were established from these samples, identified taxonomically by means of PCR amplification and subsequent sequencing of small subunit ribosomal RNA (ssrRNA) genes, and entered into the Center for Marine Microbial Ecology and Diversity (CMMED) culture collection, and cryopreserved in quintuplicate.

\subsection{Marine Microbial Extracts}

To prepare extracts for evaluation of antiviral activity, $2 \mathrm{~L}$ cultures were grown subsequent to inoculation with a cryopreserved sample. Prior to harvest of the culture, a subsample is subjected amplification and sequencing of ssrRNA genes to confirm taxonomic identity. Cultures were harvested by centrifugation at $5000 \mathrm{~g}$ for $15 \mathrm{~min}$. Supernatant medium was extracted with ethyl acetate; the ethyl acetate fraction was then evaporated to dryness; the residue was then resuspended in a small volume of ethyl acetate, and transferred to a liquid scintillation vial. Ethyl acetate was then removed under vacuum, and the vial weighed to determine the amount of material recovered. The cell pellet remaining after centrifugation was extracted in 2:1 methylene chloride: 2-propanol. The resulting organic fraction was evaporated to dryness, the residue re-suspended in a small volume of extraction solvent, and transferred to a liquid scintillation vial. The solvent was removed under vacuum, and the vial weighed to determine the amount of material recovered. The samples were then dissolved in DMSO at a concentration of $100 \mathrm{mg} / \mathrm{mL}$ and then used for screening.

\subsection{Cytotoxicity Assay by Cell Viability}

Cells at exponential growth phase were harvested by trypsin-versene solution, and seeded at $1 \times 10^{4}$ cells per well in 96-well plates. Following $24 \mathrm{~h}$ incubation at $37^{\circ} \mathrm{C}$, a confluent cell monolayer was confirmed and cell media was removed. Extracts were serially diluted with the culture medium supplemented with $10 \%$ serum to reach the concentrations of $100,50,25,12.5$ and $6.25 \mu \mathrm{g} / \mathrm{mL}$. Control dilution of DMSO at $0.1 \%$ was also included. An aliquot of $200 \mu \mathrm{L} /$ well of each diluted extract or DMSO was added to the plates in 4 replicates. The plates were incubated for 2 day at $37{ }^{\circ} \mathrm{C}$. A methylthiazol tetrazolium (MTT) assay commonly used for cell proliferation was adopted to test cell viability [27]. 


\subsection{Viral Plaque Reduction Assay}

To establish quantitative measure method, cells at exponential growth phase were harvested and seeded at $4 \times 10^{5}$ cells/well of 6 -well plates for test viruses. This cell seeding density would allow the formation of an approximately 90\% monolayer within $24 \mathrm{~h}$. Once a confluent cell monolayer was formed, cell growth medium was aspirated from the wells. Meanwhile, serial 10-fold dilutions of a virus stock were prepared and added to the plates at $200 \mu \mathrm{L} /$ well with 5 wells/viral dilution. Plates were incubated for $1 \mathrm{~h}$ at $37{ }^{\circ} \mathrm{C}$, with gentle shaking back and forth and side-to-side every 15 min to enhance even virus distribution. Residual virus was completely removed from each well and $2 \mathrm{~mL} /$ well of a $0.75 \%(\mathrm{w} / \mathrm{v})$ methylcellulose overlay medium containing $2 \%$ serum was added. Plates were then incubated for 3-4 days to allow viral plaque development. Viral plaques were visualized by the addition of $1 \mathrm{~mL} /$ well of crystal violet staining solution for at least $3 \mathrm{~h}$ [28] at room temperature followed by vigorous washing with tap water. Plaques were counted visually and the viral titer calculated as follows: Virus Titer $(\mathrm{PFU} / \mathrm{mL})=[\#$ plaques counted $\times$ dilution factor/amount of viral inoculum used $(0.2 \mathrm{~mL})]$.

\subsection{Viral Adsorption Assay-Cell Pretreatment}

Cells at an exponential growth phase were harvested and seeded at $2 \times 10^{5}$ cells per well in a 12 -well plate to allow the formation of an approximately $90 \%$ cell monolayer in $24 \mathrm{~h}$. Microbial extracts were diluted with serum-free medium to sub-toxic concentrations, as determined by the cytotoxicity test. The medium was then aspirated from the well and an aliquot of $100 \mu \mathrm{L}$ extract was added into each well. After $1 \mathrm{~h}$ incubation, the extract was aspirated from the well and the cell monolayers were rinsed twice with DPBS (Sigma-Aldrich, St. Louis, MO, USA). A prepared viral aliquot containing $25-50 \mathrm{PFU} / 100 \mu \mathrm{L}$ was added per well and the plates were incubated at $37{ }^{\circ} \mathrm{C}$ for $1 \mathrm{~h}$ to allow viral adsorption. Extracts producing a reduction in plaque formation were considered for further characterization. Antiviral effects of each extract were categorized as having no meaningful inhibition $(<20 \%)$, slight inhibition $(\geq 20 \%$ and $<50 \%)$, moderate inhibition $(\geq 50 \%$ and $<80 \%)$, or high inhibition $(\geq 80 \%)$. All experiments were conducted in triplicate.

\subsection{Viral Adsorption Assay-Virus Pretreatment}

Cells at an exponential growth phase were harvested and seeded at $2 \times 10^{5}$ cells per well into a 12 -well plate to allow the formation of an approximately $90 \%$ cell monolayer within $24 \mathrm{~h}$. Microbial crude extracts were diluted with serum-free medium to twice the sub-toxic concentrations (e.g., $200 \mu \mathrm{g} / \mathrm{mL}$ for those found to be nontoxic at $100 \mu \mathrm{g} / \mathrm{mL}$ ) as determined by the cytotoxicity tests. Viruses were diluted in serum-free medium to optimum concentrations of 50-100 PFU/well as determined by previous tests. Then, $100 \mu \mathrm{L}$ of each extract at twice the maximum sub-toxic concentration was mixed with an equal volume of the virus dilution. Positive controls were made by mixing $100 \mu \mathrm{L}$ of virus dilution with $100 \mu \mathrm{L}$ of serum-free medium with $0.2 \% \mathrm{DMSO}$, in order to yield a final DMSO concentration of $0.1 \%$. These virus-extract mixtures were pre-incubated for $1 \mathrm{~h}$ at room temperature before viral infectivity test under the optimized plaque assay conditions. Extracts leading to a reduction in plaque formation were considered for further characterization. Antiviral effect 
of each extract was categorized as having no meaningful inhibition $(<20 \%)$, slight inhibition $(\geq 20 \%$ and $<50 \%$ ), moderate inhibition $(\geq 50 \%$ and $<80 \%$ ), or high inhibition $(\geq 80 \%)$. All experiments were conducted in triplicate.

\subsection{Viral Replication Inhibition Assay}

Test cells were seeded at $4 \times 10^{5}$ cells into a TC-12.5 $\mathrm{cm}^{2}$ flask (BD Falcon, San Jose, CA, USA) to allow the formation of an approximately $90 \%$ cell monolayer within $24 \mathrm{~h}$. After the medium was completely aspirated from the flask, the cell monolayer was briefly washed twice with DPBS and then infected with selected test virus at a multiplicity of infection (MOI) of 0.001 . After $1 \mathrm{~h}$ viral adsorption, the virus was completely removed and the flask was washed twice with DPBS. Infected cultures were then incubated with medium containing $2 \% \mathrm{BCS}$ and diluted marine extracts at their safe and effective concentrations, as determined by the cytotoxicity tests. Duplicate flasks were used per test extract and these cultures were allowed to incubate for 3 days. Under the same condition, Vero cells were infected with test virus in the absence of any marine extract as a positive control. Development of viral induced CPE was documented by taking photomicrographs every $12 \mathrm{~h}$ using an inverted phase-contrast microscope equipped with a digital camera (Nikon Eclipse TE2000-U). To track viral production, $200 \mu \mathrm{L}$ aliquots of the medium were sampled from each flask every $12 \mathrm{~h}$ and stored at $-20{ }^{\circ} \mathrm{C}$ until the end of the experiment. The viral titers of these samples were later determined by the plaque assay described above. Test extracts that produced a visually noticeable reduction in CPE and reduction in viral titers were further characterized.

\subsection{Marine Microbial Extract Clean-Up and Fractionation}

Representative crude marine microbial extracts were extracted with a mixture of acetone and ethyl acetate $(1: 1, \mathrm{v} / \mathrm{v})$ under sonication for $30 \mathrm{~min}$. After the extract was dried with $10 \mathrm{~g}$ of anhydrous $\mathrm{Na}_{2} \mathrm{SO}_{4}$, it was reduced in volume to approximately $0.5 \mathrm{~mL}$ using a rotary evaporator and purified on an aluminum/silica column $(10 \mathrm{~cm} \times 8 \mathrm{~mm}$ i.d.). The column was packed, from the bottom to top, with neutral alumina $(1.5 \mathrm{~cm}, 3 \%$ deactivated), neutral silica gel $(2 \mathrm{~cm}, 3 \%$ deactivated $)$ and anhydrous $\mathrm{Na}_{2} \mathrm{SO}_{4}(1 \mathrm{~cm})$. The column was eluted with $10 \mathrm{~mL}$ acetone and ethyl acetate $(1: 1)$ to yield the target fraction. The fraction was concentrated to $20 \mathrm{~L}$ under a gentle stream of high purity nitrogen gas after $20 \mathrm{~L}$ of dodecane was added as the trapping solvent prior to gas chromatography-ion trap mass spectrometry analysis (GC-ITMS).

\subsection{GC-ITMS Analysis}

Marine microbial crude extracts were analyzed on a Varian 3800 GC and Saturn 2000 ITMS system (Varian, Walnut Creek, CA, USA) after clean-up and fractionation. An aliquot of $2.0 \mu \mathrm{L}$ of sample was injected in splitless mode with an AS8400 autosampler. The purge valve was activated 2 min after the sample injection. The column flow rate was $2 \mathrm{~mL} / \mathrm{min}$ (helium). The injector and ion trap temperatures were $280{ }^{\circ} \mathrm{C}$ and $230{ }^{\circ} \mathrm{C}$, respectively. A DB-5MS capillary column $(30 \mathrm{~m} \times 0.25 \mathrm{~mm}$ i.d., $0.25 \mu \mathrm{m}$ film thickness) was used for separation of microbial crude extracts. The oven temperature started at $90{ }^{\circ} \mathrm{C}$ for $1 \mathrm{~min}$, increased to $290{ }^{\circ} \mathrm{C}$ at a rate of $4{ }^{\circ} \mathrm{C} \mathrm{min}^{-1}$, and then held at $290{ }^{\circ} \mathrm{C}$ for $10 \mathrm{~min}$. The ITMS was operated under full ion scan mode. 


\subsection{Data Analysis}

The analysis of variance (ANOVA) tests were first performed for each sample to test the differences of variability among different concentrations. For those samples with no significant differences, the $100 \mu \mathrm{g} / \mathrm{mL}$ is used as the testing concentration for future tests. For samples with significant differences among different concentrations, an $\mathrm{IC}_{10}$ concentration was calculated based on the probit curve of the variability. All statistical analyses were performed using SPSS 16.0 software [9] with significance level controlled at $5 \%$.

\section{Conclusions}

The microbial extracts showed broad-spectrum antiviral potencies as prophylactic agents to prevent enveloped viruses infection, as evidenced by their high inhibition against all enveloped viruses tested. $5 \alpha(H), 17 \alpha(H),(20 R)-\beta$-Acetoxyergost-8(14)-ene in the marine microbial extracts was putatively identified and confirmed to be associated with antiviral activity.

\section{Acknowledgements}

The authors would like to thank the Thomas Hemscheidt laboratory for the assistance in preparation of marine microorganisms and extracts. This research was supported in part by grants from the Centers for Oceans and Human Health $(\mathrm{COHH})$ program, of the National Institutes of Environmental Health Sciences (P50ES012740), National Institutes of Health, the National Science Foundation (OCE04-32479 and OCE09-11000), the National Institute on Minority Health and Health Disparities (G12RR003061) and the National Mega Project on Major Drug Development in China (2011ZX09401-302).

\section{References}

1. Fenical, W.; Jensen, P.R. Developing a new resource for drug discovery: marine actinomycete bacteria. Nat. Chem. Biol. 2006, 2, 666-673.

2. Ausubel, J.H.; Crist, D.T.; Waggoner, P.E. First Census of Marine Life 2010: Highlights of a Decade of Discovery; Census of Marine Life: Washington, DC, USA, 2010; p. 3.

3. Donia, M.; Hamann, M.T. Marine natural products and their potential applications as anti-infective agents. Lancet Infect. Dis. 2003, 3, 338-348.

4. Faulkner, D.J. Marine natural products. Nat. Prod. Rep. 2002, 19, 1-48.

5. Fautin, D.; Dalton, P.; Incze, L.S.; Leong, J.A.C.; Pautzke, C.; Rosenberg, A.; Sandifer, P.; Sedberry, G.; Tunnell, J.W.; Abbott, I.; et al. An overview of marine biodiversity in United States waters. PLoS One 2010, 5, e11914.

6. Tissot, B.N.; Walsh, W.J.; Hixon, M.A. Hawaiian islands marine ecosystem case study: ecosystem- and community-based management in Hawaii. Coast. Manag. 2009, 37, 255-273.

7. Hill, R.T.; Fenical, W. Pharmaceuticals from marine natural products: Surge or ebb? Curr. Opin. Biotechnol. 2010, 21, 777-779. 
8. Mayer, A.M.; Glaser, K.B.; Cuevas, C.; Jacobs, R.S.; Kem, W.; Little, R.D.; McIntosh, J.M.; Newman, D.J.; Potts, B.C.; Shuster, D.E. The odyssey of marine pharmaceuticals: A current pipeline perspective. Trends Pharmacol. Sci. 2010, 31, 255-265.

9. SPSS Statistics Software, version 16.0; SPSS Inc.: Chicago, IL, USA, 2007.

10. Sica, D.; Musumeci, D. Secosteroids of marine origin. Steroids 2004, 69, 743-756.

11. Mayer, A.M.; Gustafson, K.R. Marine pharmacology in 2005-6: Antitumour and cytotoxic compounds. Eur. J. Cancer 2008, 44, 2357-2387.

12. Mayer, A.M.; Rodriguez, A.D.; Berlinck, R.G.; Hamann, M.T. Marine pharmacology in 2005-6: marine compounds with anthelmintic, antibacterial, anticoagulant, antifungal, anti-inflammatory, antimalarial, antiprotozoal, antituberculosis, and antiviral activities; affecting the cardiovascular, immune and nervous systems, and other miscellaneous mechanisms of action. Biochim. Biophys. Acta 2009, 1790, 283-308.

13. Verkman, A.S. Drug discovery in academia. Am. J. Phys. Cell Phys. 2004, 286, C465-C474.

14. Toranzo, A.E.; Barja, J.L.; Hetrick, F.M. Antiviral activity of antibiotic-producing marine bacteria. Can. J. Microbiol. 1982, 28, 231-238.

15. Denis, F.; Brisou, J.F.; Dupuis, T. Inactivation of enteroviruses in seawater. C. R. Acad. Sci. Hebd. Seances Acad. Sci. D 1975, 281, 471-474.

16. Magnusson, S.; Gundersen, K.; Brandberg, A.; Lycke, E. Marine bacteria and their possible relation to the virus inactivation capacity of sea water. Acta Pathol. Microbiol. Scand. 1967, 71, 274-280.

17. Gundersen, K.; Brandberg, A.; Magnusson, S.; Lycke, E. Characterization of a marine bacterium associated with virus inactivating capacity. Acta Pathol. Microbiol. Scand. 1967, 71, 281-286.

18. Yasuhara, B.J.; Lu, Y.A. Marine compounds and their antiviral activities. Antiviral Res. 2010, 86, 231-240.

19. Yasuhara-Bell, J.; Yang, Y.; Barlow, R.; Trapido-Rosenthal, H.; Lu, Y. In vitro evaluation of marine-microorganism extracts for anti-viral activity. Virol. J. 2010, 7, 182.

20. Lee, J.B.; Hayashi, K.; Hirata, M.; Kuroda, E.; Suzuki, E.; Kubo, Y.; Hayashi, T. Antiviral sulfated polysaccharide from Navicula directa, a diatom collected from deep-sea water in Toyama Bay. Biol. Pharm. Bull. 2006, 29, 2135-2139.

21. Prestegard, S.K.; Oftedal, L.; Coyne, R.T.; Nygaard, G.; Skjaerven, K.H.; Knutsen, G.; Doskeland, S.O.; Herfindal, L. Marine benthic diatoms contain compounds able to induce leukemia cell death and modulate blood platelet activity. Mar. Drugs 2009, 7, 605-623.

22. Ianora, A.; Poulet, S.A.; Miralto, A. The effects of diatoms on copepod reproduction: A review. Phycologia 2003, 42, 351-363.

23. Lebeau, T.; Robert, J.M. Diatom cultivation and biotechnologically relevant products. Part I: Cultivation at various scales. Appl. Microbiol. Biotechnol. 2003, 60, 612-623.

24. Da Poian, A.T.; Gomes, A.M.O.; Coelho-Sampaio, T. Kinetics of intracellular viral disassembly and processing probed by Bodipy fluorescence dequenching. J. Virol. Methods 1998, 70, 45-58.

25. Enwall, E.L.; van der Helm, D.; Hsu, I.N.; Pattabhiraman, T.; Scmitz, F.J.; Spraggins, R.L.; Weinheimer, A.J. Crystal structure and absolute configuration of two cyclopropane containing marine steroids. J. Chem. Soc., Chem. Commun. 1972, 4, 215-216. 
26. Lu, Y.N.; Aguirre, A.A.; Wang, Y.; Zeng, L.B.; Loh, P.C.; Yanagihara, R. Viral susceptibility of newly established cell lines from the Hawaiian monk seal Monachus schauinslandi. Dis. Aquat. Organ. 2003, 57, 183-191.

27. Mosmann, T. Rapid colorimetric assay for cellular growth and survival: Application to proliferation and cytotoxicity assays. J. Immunol. Methods 1983, 16, 55-63.

28. Lu, Y.N.; Loh, P.C. Some biological properties of a rhabdovirus isolated from penaeid shrimps. Arch. Virol. 1992, 127, 339-343.

Samples Availability: Available from the authors.

(C) 2012 by the authors; licensee MDPI, Basel, Switzerland. This article is an open access article distributed under the terms and conditions of the Creative Commons Attribution license (http://creativecommons.org/licenses/by/3.0/). 